\title{
THE EFFECT OF TASK-BASED LEARNING METHOD ON STUDENTS' ACHIEVEMENT IN WRITING PROCEDURE TEXT
}

\author{
*Ade Suryani Nasution \\ **Masitowarni Siregar
}

\begin{abstract}
This study aims at investigating the effect of Task-Based Learning Method on students' achievement in writing a procedure text. This study was experimental in nature. The population of this study was the first year students at SMA Negeri 2 Tanjung Balai. The total number of the population was 280 students in seven classes. There were 60 students chosen as the sample by using random sampling technique. The sample was divided into two groups, namely control group and experimental group. The experimental group was taught by using Task-Based Learning Method and control group was taught without using Task-Based Learning Method. The instrument for collecting the data was a writing test. To obtain test reliability, the writer applied the Pearson Product Formula. The calculation showed that the reliability of the test was 0.90 . It was categorized as very high reliability. The data were analyzed by using the $t-$ test formula. The result of the analysis showed that the t-observed value was higher than t-table $(2.34>2.00)$ at the level of significance 0.05 with a freedom degree of 58 . It means that the alternative hypothesis (Ha) was accepted and the null hypothesis (Ho) was rejected. Based on the findings of this study, it was found that there was a significant effect of Task-Based Learning Method on students' achievement in writing procedure texts.
\end{abstract}

Key Words: Task-Based Learning, Writing, Procedure Text.

* A graduate of English Language and Literature Department of UNIMED 
** A lecturer of English Language and Literature Department of UNIMED

\section{INTRODUCTION}

\section{Background of the Study}

Writing is an essential part of learning a language. It is the most important skills in language learning besides the other language skills namely reading, speaking, and listening. It is one of the standard competences in the teaching of English. Mastering writing ability effectively is seen as a key objective for senior high school students. (Harmer, 2004:13). Writing skill is a specific ability which helps writers put their thoughts into words in a meaningful form and mentally interact with the message. Hyland (2002:88) defines that writing is generative in which writers can explore and discover ideas as they write. So, by writing students can express their knowledge, ideas, messages, and feelings into the form of letters and convey their messages to the readers.

Writing encourages and emphasizes the abilities of students in using language skills based on the context or situation within their environment. In writing, students also have to understand some types of genre with various purposes of communication and should be matched with students' level of education. According to The Units Curriculum of Education Level (KTSP), SMA students are expected to be able to write recount, narrative, descriptive, procedure, report, spoof, and exposition texts. One of the texts learned in Senior High School (Sekolah Menengah Atas; SMA) is a Procedure Text.

Writing is actually challenging and complicated. It concerns many elements such as content, grammar, vocabulary, form, cohesion and coherence, specific structures for each genre, and functional text. Based on the writer's Teaching Practice Program (Praktek Pengalaman Lapangan: PPL) at SMP Negeri 1 Bangun Purba, it was not easy for the students to write well in English. Many students got difficulties to develop their writing because of many factors such as lack of vocabularies; motivation and limited grammar. These things make students uninterested in writing.

Teachers can make writing enjoyable for students by using a variety of activities, approaches, methods, strategies and techniques. Based on the explanation above, the writer is interested in applying Task-Based Learning Method in the classroom. 
In task-based learning, the students are learning by doing. The focus of the lesson is the task, not the structure. In other words, students are given a task to perform and when the task has been completed, the teacher discusses the language used, making correction and adjustments of the students' performance.

Most of our daily activities are related with procedures and process. We often have to perform some steps to get something done. That is why the students should understand what a procedure text is, how to make and use it.

\section{Research Question}

The problem of the study was formulated as the following: Does the effect of Task-Based Learning method improve writing achievement of the students of the first grade at SMA Negeri 2 Tanjung Balai? This research focused on how Task-Based Learning Method effects the students' achievement in writing a procedure text.

\section{Objective of the Study}

It is expected that this method will give a positive effect on the students' learning process.

\section{Significance of the Study}

The study was aimed at finding out if there was any significant effect of Taskbased learning on the achievement of the first year students of SMA Negeri 2 Tanjung Balai in writing a procedure text. It is expected that this study will give some contribution to language teaching and learning. The results of the study are expected to be useful for:

a. Teachers who are motivated to apply this method as an alternative to teach procedure text writing.

b. Other researchers interested in applying this method as the basic information of how to develop students' achievement in writing a procedure text. 


\section{Conceptual Framework}

\section{Writing Procedure Text by Using Task-Based Learning}

Writing is one of the language skills used by people to convey their messages. It is also used to express ideas, feelings, thoughts, etc. In writing, a writer needs the words and organizational structures that make the words convey the writers' ideas or messages through development and coherence. Writing serves as the most available and the most compelling way because the outcome, visible language, is a satisfying permanent record of thoughts and feelings. Writing is the mental work of the inventions ideas, thinking about how to express them into statement and paragraph that will be clear to a reader.

In addition, writing should be organized effectively and includes aspects such as word choice, grammar, mechanics, and content or evidence. It means that writing should communicate something clearly, precisely, and unambiguously, so that the readers can comprehend the writer of what is being written about.

Writing has some benefits for students in their learning process for the following reasons:

a. Students' awareness and appreciation of the different purposes of reading increase.

b. Through writing, students see the difference between written and oral language.

c. Writing is particularly good for reinforcement of vocabulary, grammar, and structure.

d. When students write their own reflections on an activity, they strengthen the ideas that they have learned through reading and listening.

Genre is very important in writing. Students who are writing with a certain genre need to consider a number of different factors. They need to have knowledge of the topic, the conventions and style of the genre, and the context in which their writing will be read, and by whom. In the classroom, an awareness of these contextual and 
genre variations is more likely to enhance students writing skills than assumptions of distend categories of language use (Hyland, 2002:53).

Procedure text is kind of text which teaches how to do or make something completely. For this reason, procedure text generally begins with the goal of the task, which is usually stated as heading. Procedure text is dominantly structured with imperative sentence since it actually an instruction.

Task based learning is a different way to teach languages. It can help students by placing them in real-life situations, where oral communication is essential for doing a specific task. Task based learning has the advantage of getting students to use their skills at their current level, developing language through its use. It has the advantage of placing the focus of students toward achieving a goal where language becomes a tool, making the use of language a necessity.

In the model of task-based learning described by Jane Willis, the traditional PPP (presentation, practice, production) lesson is reversed. The students start with the task. When they have completed it, the teacher draws attention to the language used, making corrections and adjustments to the students' performance. By using the method, students can discuss and share their views in writing of procedure text so they can effectively write without being stuck, because they can interact with their friends and not be passive in the class.

\section{METHODOLOGY}

\section{Research Design}

This study was conducted by using an experimental design. Experimental design was used to establish cause and effect by manipulating an independent variable to see its effect on a dependent variable. It was a design in which the writer manipulated at least one independent variable and its effect on one dependent.

In this study, the task-based learning method was an independent variable and writing ability was as dependent variable. In this research design, there were two groups of student namely experimental group and control group. Both groups were given pretest and post-test. The experimental group was taught by using the task-based learning 
method while the control group was taught without using the task-based learning method.

\section{Population}

The population of this study was the first year students at SMA Negeri 2 Tanjung Balai in the 2011/2012 academic year. There were 7 parallel classes. The total number of the students was two hundred eighty students. In selecting the sample, the writer used a Random Sampling Technique. Two classes were taken as the sample. The experimental group was class X.1 and the control group was class X.6. The experimental group was taught by using a Task-Based Learning method while the control group was taught by using a conventional method (Teacher-Centered Learning).

This study used an essay test as an instrument to collect the data. In this case, the writer gave a topic "How to make an omelet" and asked them to produce a procedure text on the title given. in the pre test and in post test the students were asked to write a procedure text on their own title.

In order to get the data in this study, three procedures were taken by the writer namely: pre-test, treatment (teaching presentation), and post test.

\section{$>$ Pre-Test}

The pre-test was given to both groups (experimental group and control group) before the treatment. The pre test was used to know the mean scores of the experimental group and control group before receiving the treatment. The students were asked to write a text.

$>$ Treatment

After the pre-test, three treatments were carried out to both experimental and control group. The topics used in the three meetings were:

a. How to make tea

b. How to make an avocado juice

c. How to make a sandwich

The experimental group was taught by using a Task-based learning method in writing. In the control group, the students were taught by using a conventional method (teacher-centered learning) on students writing. In the control group, the students were 
taught by applying a conventional method (teacher-centered learning). The students were asked to open their English book in getting some information about a procedure text.

$>$ Post - Test

After teaching both the experimental and control groups, the teacher gave a post test to each student in both groups in order to know their mean scores. The writer used the post test to know the effect of Task-based learning method on students' achievement in writing a procedure text.

\section{Validity and Reliability}

This research used an essay test. Essay test was the method for getting students to produce a sample of connected writing.

Gronlund (1998:226) in Brown (2004) states that validity is the extent to which inferences made from assessment results are appropriate, meaningful, and useful in terms of the purpose of the assessment. It means that the researcher is concerned with how well a test determines whether or not students have reached a set of goals or level of competence. In this case, the researcher wanted to know whether the test given could measure the students' achievement in writing a procedure text or not by choosing the topic which was adjusted based on the curriculum implemented in the senior high school text book.

Reliability is a necessary indicator of a good test, for a test to be valid; a test should be first reliable as measuring instrument. If the test is administrated to the same candidates on different occasions and produces differing results, it might be unreliable.

The concept of reliability is referred to as the consistency of measurement. Brown (2004: 20) states that reliable test are consistent and dependable. If the researcher gives the same test to the same student or matches students on two different occasions, the results of the test are similar. The test used in this research was a writing test. The scoring of the writing test involved the subjectivity. Thus to find out whether or not the test was reliable, the writer applied inter-rater reliability by applying coefficient correlation. The writer used the results of pre-test from two different groups; experimental group and control group. 
The coefficient correlation could be obtained by applying a Pearson Product Formula as follows:

$$
r_{x y}=\frac{N\left(\sum X Y\right)-\left(\sum X\right)\left(\sum Y\right)}{\sqrt{\left\{N \sum X^{2}-\left(\sum X\right)^{2}\right\}\left\{N \sum Y^{2}-\left(\sum Y\right)^{2}\right\}}}
$$

Where:

$\mathrm{r}=$ the reliability of the test

$\sum \mathrm{x}=$ sum of scorer $\mathrm{x}$

$\sum \mathrm{y}=$ sum of scorer $\mathrm{y}$

$\mathrm{N}=$ the number of students

In order to measure whether or not the test is reliable, according to Aruan (2007), the reliability of the test can be categorized as follows:

$0,00-0,20-$ very low reliability

$0,20-0,40-$ low reliability

$0,40-0,60$ - fair reliability

$0,60-0,80-$ high reliability

$0,80-0,100-$ very high reliability

\section{Technique for Analyzing Data}

In order to find out the difference mean of the two groups, the writer used the $\mathrm{t}-$ test formula. The result of data was used to differentiate the results of t-test and t-table in order to find out if the task-based learning gives a positive or negative effect on the students' achievement in writing a procedure text. T-test formula can be seen as follows:

$$
t=\frac{M a-M b}{\sqrt{\left(\frac{d a^{2}+d b^{2}}{N a+N b-2}\right)\left(\frac{1}{N a}+\frac{1}{N b}\right)}}
$$

Where:

$\mathrm{Ma}=$ the mean of the experimental group

$\mathrm{Mb}=$ the mean of the control group

$\mathrm{da}=$ the standard deviation of the experimental group

$\mathrm{db}=$ the standard deviation of the control group

$\mathrm{Na}=$ the total number of the experimental group 
$\mathrm{Nb}=$ the total number of the control group

\section{RESULTS AND DISCUSSION}

\section{Data}

The data of this study were obtained from the pre-test and post-test given to experimental and control group. The data contained students' scores needed for the hypothesis testing. Based on the data, the mean score of the experimental group in pretest and post-test was higher than that of the control group. The mean of the experimental group in pre-test was 67.1 and control group was 48.5. Meanwhile, the mean of the experimental group in post-test was 80.6 and control group was 56 .

$>$ Experimental group

In the pre-test, the lowest score was 42 and the highest score was 82 whereas in the post-test, the lowest score was 45 and the highest score was 95. Among 30 students, there was only a student whose score was lower in the post-test than in pre-test whereas the MIQ's score of the pre-test was 64 and post-test was 45 .

Control group

In the pre-test, the lowest score was 32 and the highest score was 67 whereas in the post-test, the lowest score was 38 and the highest score was 75 . Among 30 students, there were three students whose score was lower in the post-test than the pre-test. They were AIA, ISM, and MSY where as AIA got 41 in the posttest and 38 in the pre-test, ISM got 60 in the pre-test and 50 in the post-test, and MSY got 47 in the pre-test and 40 in the post-test.

The data to be analyzed were obtained by giving a writing test to the students in order to know their procedure text writing ability. It was calculated by using scores of the writing test in both the experimental and control groups. The analysis of data was conducted through pre-test and post-test in both groups, the scores of the experimental and control group were computed by applying a t-test formula to prove the hypothesis in this study. 
From the calculation, the t-test was 2.34. It was found that there was a significant effect of Task-Based Learning method on the students' achievement in writing a procedure text.

\section{Research Findings}

The objective of this research was to find out if there was a significant effect of Task Based Learning Method on the students' achievement in writing a procedure text. It was found that the mean of the experimental group $(80,6)$ was higher than that of the control group (56). The result of the calculation showed that the $t_{\text {obs }}$ value (2.34) was higher than the $\mathrm{t}_{\text {table }}$ value $(2.000)$ or $\mathrm{t}_{\mathrm{obs}}>\mathrm{t}_{\text {table }}=2.34>2.000(0.05)$. The students taught by using the Task-Based Learning method got higher scores than those taught without using the Task-Based Learning method. The result of the t-test showed that, the t-test was higher than the t-table $(2.34>2.000)$. Ha was accepted and Ho was rejected.

It means that there was a significant effect of Task-Based Learning method on the students' achievement in writing a procedure text.

\section{Testing Hypothesis}

The formulas of t-test and distribution table were applied in order to discover whether the hypothesis was accepted or rejected.

After calculating the data, the writer found that the t-test was 2.34. It means that the $\mathrm{t}$-test was higher than that of the t-table with a degree of freedom (df) $\mathrm{Na}+\mathrm{Nb}-2=$ 58 at $\mathrm{p}(0.05)=(2.34>2.000)$.

Based on the calculation of the t-test, it could be concluded that Ha was accepted and Ho was rejected. It was found that there was a significant effect of the Task-Based Learning method on the students' achievement in writing a procedure text.

\section{CONCLUSION AND SUGGESTIONS}

\section{Conclusion}

The calculation result of the t-test showed that the $t_{\text {-test }}$ value 2.34 with a degree of freedom $(\mathrm{df})=58$ was higher than the $t_{\text {table }} 2.000$ at the level significance $(p=0.05)$ implying that the alternative hypothesis (Ha) was accepted and the null hypothesis (Ho) was rejected. Therefore, there was a significant effect of Task-Based Learning Method 
on the achievement of the first year students of SMA Negeri 2 Tanjung Balai in writing a procedure text.

\section{Suggestions}

Based on the result of the study, suggestions can be made as the following:

a. Teachers can apply the Task-Based Learning method as an alternative and interesting method in teaching how to write a procedure text, because it can improve students' achievement in writing a procedure text.

b. Other researchers who are interested in applying this method can use it as the basic information to develop students' achievement in writing a procedure text.

\section{REFERENCES}

Aruan, D.M. 2007. Penafsiran Skor Test [Bachelor's thesis]. Medan: State University of Medan.

Brown, H. D. 2001. Teaching by Principles. An Interactive Approach to Language Pedagogy (2nd Ed.). New York: Pearson Education Company.

Brown, H. D. 2004. Language Assessment: Principles and Classroom Practices. San Francisco: Longman.

Curran, P. 2006. Task-Based Learning (TBL). http://youth-partnership-eu.coe.int/youthpartnership/documents/Publications/T kits/2/2 task.pdf. Retrieved September 29, 2011.

Dora, K., Betzabel, P., \& Elena, M. 2010. Task-Based Learning. http://blogs.funiber.org/formacion-profesores/2010/02/17/task-based-learning/. Retrieved September 29, 2011.

Harmer, J. 2004. How to Teach Writing. New York: Longman.

Harmer, J. 2003. The Practice of English Language Teaching (3rd Ed.). Cambridge: Longman 
Hyland, K. 2002. Teaching and Researching Writing. London: Pearson Education.

Knapp, P., \& Watkins, M. 2005. Genre, Text, Grammar: Technologies for Teaching and Assessing Writing. Sydney: University of New South Wales.

Langan, J. 2001. College Writing Skills with Reading. New York: Mc Graw Hill.

Leonhad, K. 2003. Task-Based Learning Presentation. http://www.etlc.ntust.edu.tw/data/090425/TBL_presentation.pdf. Retrieved September $30,2011$.

Nazrean, A. 2006. Task-Based Learning in Education. http://www.upm.ro/facultati departamente/stiinte litere/conferinte/situl integrare eur opeana/Lucrari3/engleza/74 ANDREEA\%20NAZNEAN2.pdf. Retrieved September 30, 2011 .

Pools-m, T. 2010. Task Based Learning. http://www.languages.dk/archive/poolsm/manuals/TBL.pdf. Retrieved September 29, 2011.

Raynal. 2010. Procedure Text. http://raynal.wordpress.com/2010/02/27/proceduretext/. Retrieved September 30, 2011.

Ruso, N. 2007. The Influence of Task Based Learning on EFL Classrooms. http://faculty.ksu.edu.sa/yousif/3422/The\%20influence\%20of\%20TBL.pdf. Retrieved September 29, 2011.

Stott, R., \& Simon, A. 2001. Writing with Style. London: Longman.

Tiwari, D. 2005. Encyclopedia of Modern Methods of Teaching. New Delhi: Crescent. 